\title{
Studi Analisis Batasan Persentase Prategang Parsial pada Struktur Balok Prategang
}

\author{
DEVY YOLANDA, PRIYANTO SAELAN
}

\author{
Jurusan Teknik Sipil, Institut Teknologi Nasional, Bandung \\ Email: devydudu@gmail.com
}

\begin{abstract}
ABSTRAK
Pengurangan gaya prategang yang diperlukan pada suatu penampang beton prategang penuh (full prestressed) menyebabkan diperlukannya baja tulangan, dan beton prategang berperilaku menjadi beton prategang parsial. Pengurangan gaya prategang akan menimbulkan tegangan tarik yang bilamana tegangan tarik yang terjadi melampaui kuat tarik lentur beton maka akan terjadi retak. SNI 03-2847-2002 membolehkan penggunaan beton prategang parsial namun belum mensyaratkan batasan persentase prategang yang harus digunakan. Oleh karena itu dilakukan studi analisis untuk mengetahui persentase prategang minimal yang dapat digunakan. Studi kasus dilakukan pada persentase prategang 50, 60, 70, 80, dan 90. Dari hasil studi kasus didapatkan bahwa persentase prategang yang semakin kecil akan berakibat tegangan tarik dan lebar retak yang terjadi semakin besar. Persentase prategang harus dipilih sedemikian rupa sehingga lebar retak yang terjadi tidak melampaui lebar retak yang diizinkan. Pada kelima variabel penelitian, batasan minimal persentase prategang yang lebar retaknya tidak melebihi lebar retak yang diizinkan adalah $60 \%$.
\end{abstract}

Kata kunci: beton prategang parsial, persentase prategang, tegangan tarik, lebar retak

\section{ABSTRACT}

Reducing the required prestressing force on a full prestressed concrete section requires the need for reinforcing steel, and prestressing concrete behaves to partial prestressed concrete. Reduction of the prestressing force will cause tensile stress when the tensile stress that goes beyond the tensile strength of the concrete will result in cracking. SNI 03-2847-2002 allows the use of partial prestressed concrete but does not require the limitation of the prestress percentage to be used. Therefore, an analytical study was conducted to determine the minimum prestressed percentage that can be used. The case study was carried out at 50, $60,70,80$, and 90 prestressed percentages. From the case study it was found that the smaller the prestress percentage would result in greater tensile stress and crack width. The percentage of prestress shall be chosen so that the crack width does not exceed the allowable crack width. In the five research variables, the minimum limit of prestressing percentage whose crack width does not exceed the allowable crack width is $60 \%$.

Keywords: partial prestressed concrete, prestress percentage, tensile stress, crack width 


\section{PENDAHULUAN}

Beton prategang dibedakan menjadi 2 macam berdasarkan kondisi keutuhan penampang, yaitu prategang penuh ( Full Prestressed) dan prategang sebagian/parsial ( Partial Prestressed). Pada prategang penuh tidak diizinkan terjadinya tegangan tarik sehingga penampang berada dalam keadaan tertekan, sedangkan pada prategang parsial, gaya prategang penuh dikurangi dan pengurangan gaya prategang ini diganti dengan pemasangan baja tulangan sedemikian rupa sehingga kapasitas lentur dalam keadaan beban batas tetap sama. Semakin tinggi pengurangan gaya prategang pada beton prategang parsial akan mengakibatkan tegangan tarik yang makin besar walaupun kapasitas lenturnya tetap sama dengan kapasitas lentur beton prategang penuh. Jika tegangan tarik semakin besar maka lebar retak pada beton prategang parsial akan semakin besar yang akan membahayakan kabel prategang dari korosi, dan akan menyebabkan makin besarnya lendutan.

Tujuan dari studi analisis ini adalah untuk mengetahui persentase prategang minimum yang diperbolehkan pada beton prategang parsial sesuai dengan standar perancangan beton prategang dalam SNI 03-2847-2002. Manfaat yang diharapkan dari studi analisis ini adalah mengetahui perilaku beton prategang parsial sesuai dengan persentase prategangnya dan hasil dari studi analisis ini dapat digunakan menjadi salah satu rujukan dalam perancangan beton prategang parsial.

\section{KAJIAN PUSTAKA}

\subsection{Beton Prategang}

Beton prategang merupakan struktur komposit dari material beton dan baja dengan mutu tinggi. Baja yang digunakan disebut tendon, yaitu beberapa baja yang dikelompokkan dan membentuk kabel. Prinsip kerja dari beton prategang yaitu tendon ditegangkan diawal dengan cara ditarik untuk memberikan tegangan tekan pada penampang beton sebelum adanya beban yang bekerja pada struktur.

\subsection{Analisis Penampang Balok Prategang Penuh Terlentur (Full Prestressed)}

Analisis penampang balok prategang terlentur dilakukan berdasarkan perhitungan tegangan pada penampang pada kondisi elastis, yaitu pada kondisi beban kerja (service load) seperti pada Gambar 1.

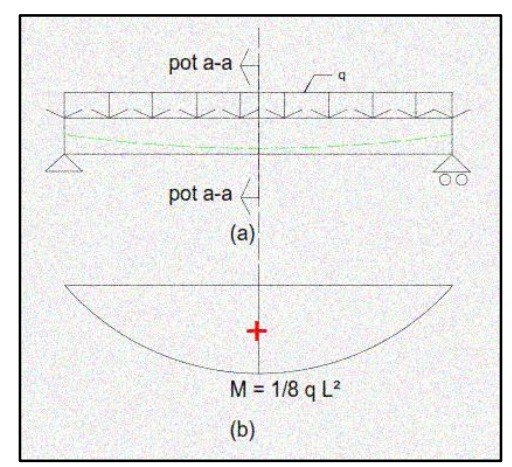

Gambar 1. (a) Balok prategang penuh pada dua perletakan sederhana dengan beban merata $q$; (b) momen maksimum di tengah bentang

Pada Gambar 1.a balok prategang penuh yang berada pada dua perletakan sederhana yaitu sendi-rol memikul beban mati dan beban hidup yang terbagi merata dengan intensitas $q$, dan Gambar 1.b beban merata $q$ akan menimbulkan momen maksimum yang terjadi di tengah bentang pada balok prategang penuh. 
Tegangan pada penampang balok prategang pada serat atas dan serat bawah dapat dilihat pada Persamaan 1 dan Persamaan 2.

$$
\begin{gathered}
\sigma_{a}=-\frac{M y_{a}}{I}-\frac{P}{A}+\frac{P e y_{a}}{I} \\
\sigma_{b}=\frac{M y_{b}}{I}-\frac{P}{A}-\frac{P e y_{b}}{I}
\end{gathered}
$$

halmana:

$\sigma_{a}=$ tegangan di serat atas, $\left[\mathrm{kg} / \mathrm{cm}^{2}\right]$,

$\sigma_{b}=$ tegangan di serat bawah, $\left[\mathrm{kg} / \mathrm{cm}^{2}\right]$,

$I=$ momen inersia, $\left[\mathrm{cm}^{4}\right]$,

$e=$ eksentrisitas kabel, $[\mathrm{cm}]$,

$P=$ gaya prategang, $[\mathrm{kg}]$,

$M=$ momen di tengah bentang untuk tiap kondisi, [kgm],

$y_{a}=$ jarak serat atas dari titik berat, $[\mathrm{cm}]$,

$y_{b}=$ jarak serat bawah dari titik berat, $[\mathrm{cm}]$.

Perjanjian tanda:

Tegangan tekan : [ - ]

Tegangan tarik : $[+]$

Tegangan pada penampang balok beton prategang penuh dapat dilihat pada Gambar $\mathbf{2}$.

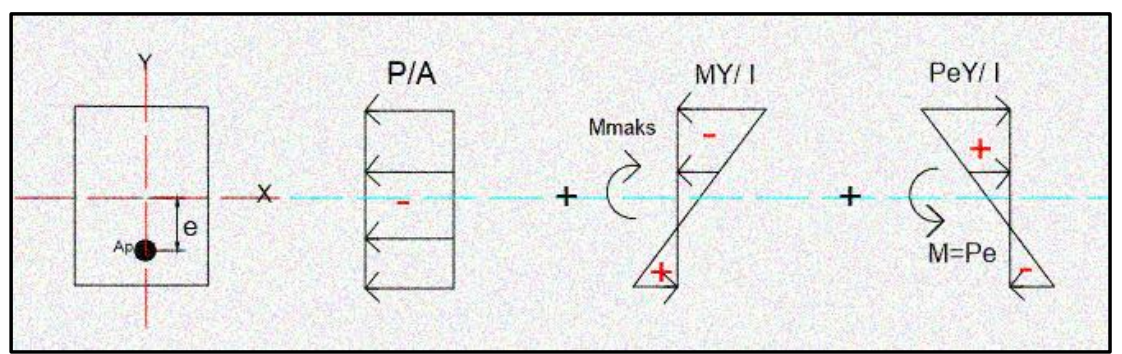

Gambar 2. Kondisi tegangan pada penampang balok beton prategang penuh

Kondisi pembebanan balok prategang terdiri dari beberapa kondisi, yaitu:

(a) saat pembangunan, dimana pada saat ini beban yang dipikul balok adalah berat sendiri balok;

(b) saat selesai pembangunan dan bangunan dalam keadaan tak digunakan, dimana beban yang dipikul balok adalah berat sendiri balok dan beban mati lainnya;

(c) saat bangunan digunakan, dimana beban yang bekerja adalah berat sendiri balok, beban mati lainnya, dan beban hidup.

Jika tegangan tarik tidak diperbolehkan pada beton, tegangan beton dan besarnya tegangan batas izin sesuai 3 kondisi pembebanan dapat dilihat pada Gambar 3.

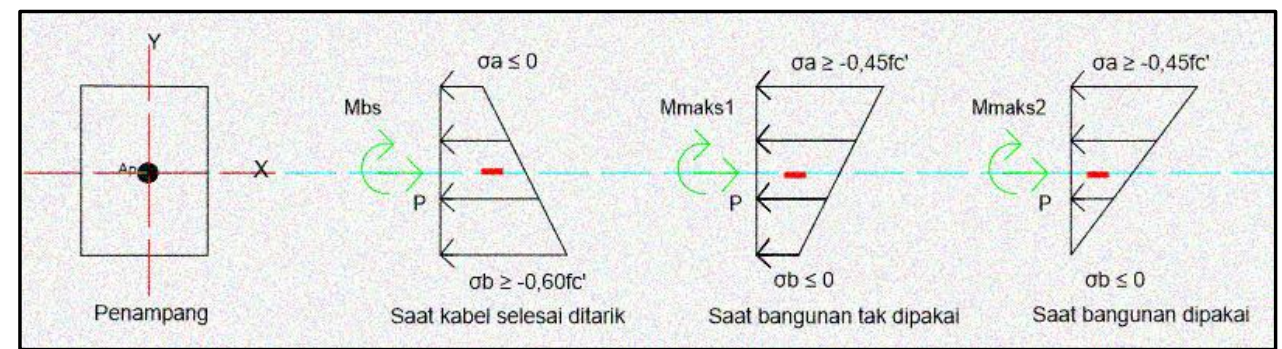

Gambar 3. Tegangan penampang dan besar tegangan batas izin pada beton berdasarkan kondisi penampang

Reka Racana - 50 
Besarnya tegangan beton yang diizinkan pada penampang beton prategang diatur dalam SNI 03-2847-2002.

1. Tegangan beton sesaat sesudah penyaluran gaya prategang (sebelum terjadinya kehilangan tegangan sebagai fungsi waktu) tidak boleh melampaui nilai berikut:

(a) tegangan serat tekan terluar $0,60 f_{c i}^{\prime}$;

(b) tegangan serat tarik terluar kecuali seperti yang diizinkan $0,25 \sqrt{f_{c i}{ }^{\prime}}$;

(c) tegangan serat tarik terluar pada ujung-ujung komponen struktur di atas perletakan sederhana $0,5 \sqrt{f_{c i}{ }^{\prime}}$.

2. Tegangan beton pada kondisi beban layan (sesudah memperhitungkan semua kehilangan prategang yang mungkin terjadi) tidak boleh melampaui nilai berikut:

(a) tegangan serat tekan terluar akibat pengaruh prategang, beban mati dan beban hidup tetap $0,45 f_{c}^{\prime}$;

(b) tegangan serat tekan terluar akibat pengaruh prategang, beban mati dan beban hidup total $0,60 f_{c}{ }^{\prime}$;

(c) tegangan serat tarik terluar dalam daerah tarik yang pada awalnya mengalami tekan $0,5 \sqrt{f_{c}{ }^{\prime}}$.

\subsection{Beton Prategang Parsial}

Beton prategang parsial merupakan kombinasi dari penggunaan beton prategang dan beton bertulang. Untuk struktur yang jarang mengalami beban berlebih maka dapat digunakan beton prategang parsial. Penggunaan desain beton prategang parsial akan menghemat jumlah kabel prategang yang dipakai, namun agar kekuatan batas pada beton prategang parsial dan beton prategang penuh tetap sama, maka harus digunakan sejumlah baja tulangan.

Perbandingan tegangan yang terjadi pada penampang balok prategang penuh dan prategang sebagian dapat dilihat pada Gambar 4.

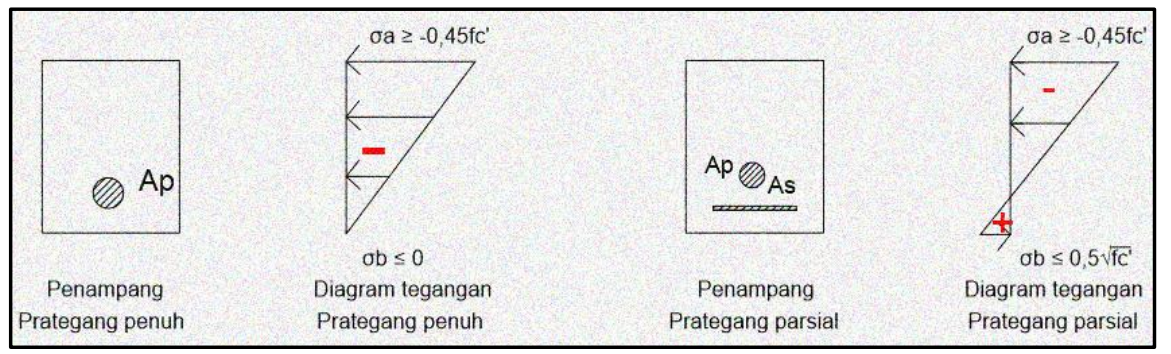

\section{Gambar 4. Penampang dan diagram tegangan dari balok prategang penuh} dan prategang parsial

Dari Gambar 4 dapat dilihat bahwa diagram tegangan pada penampang balok prategang penuh sama sekali tidak diperbolehkan terjadi tegangan tarik $\left(\sigma_{b} \leq 0\right)$, sedangkan diagram tegangan pada penampang balok prategang parsial terjadi tegangan tarik namun dibatasi $\left(\sigma_{b} \leq 0,5 \sqrt{f_{c}^{\prime}}\right)$.

Untuk balok prategang parsial diatas dua perletakan sederhana, tegangan pada serat terluar pada penampang di tengah bentang adalah seperti pada Persamaan 3 dan Persamaan 4.

$$
\begin{gathered}
\sigma_{a}=-\frac{M y_{a}}{I}-\frac{P}{A}+\frac{P e y_{a}}{I} \leq-0,45 f_{c}{ }^{\prime} \\
\sigma_{b}=\frac{M y_{b}}{I}-\frac{P}{A}-\frac{P e y_{b}}{I} \geq 0
\end{gathered}
$$


halmana:

$f_{c}{ }^{\prime}=$ kuat tekan beton yang disyaratkan, [MPa].

Analisis penampang prategang parsial dilakukan pada keadaan/kondisi batas (ultimate).

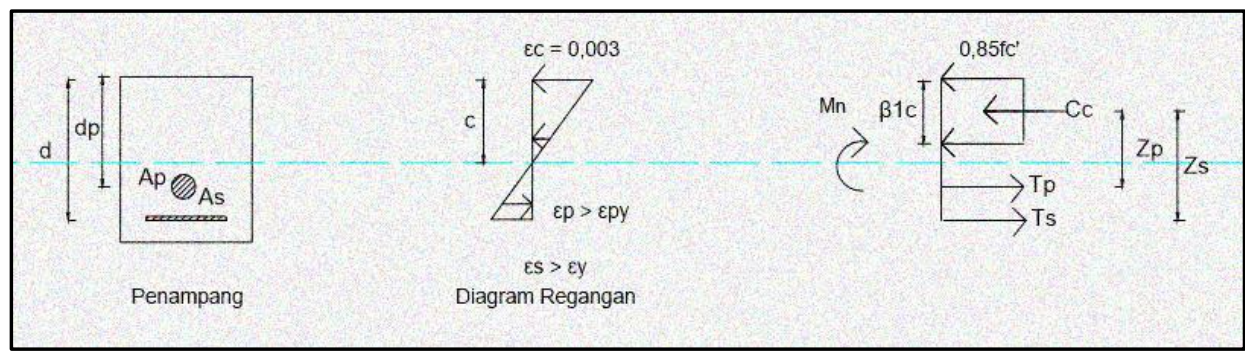

Gambar 5. Regangan dan tegangan pada penampang balok prategang parsial

Dari Gambar 5 dengan hukum keseimbangan maka didapat Persamaan 5.a dan Persamaan 5.b.

halmana:

$$
\begin{gathered}
M_{n}=T_{p} * Z_{p} * T_{s} * Z_{s} \\
\Leftrightarrow M_{n}=M_{p}+M_{s}
\end{gathered}
$$

$M_{n}=$ momen lentur nominal penampang, $[\mathrm{Nmm}]$,

$T_{p}=$ gaya pada kabel prategang, $[\mathrm{N}]$,

$Z_{p}=$ lengan momen untuk gaya pada kabel prategang, [mm],

$T_{S}$ = gaya pada tulangan tarik, [N],

$Z_{s}=$ lengan momen untuk gaya pada tulangan tarik, [mm],

$M_{p}=$ bagian $M_{n}$ yang dipikul oleh $A_{p},[\mathrm{Nmm}]$,

$M_{s}=$ bagian $M_{n}$ yang dipikul oleh $A_{s},[\mathrm{Nmm}]$.

Persentase prategang yang kecil pada balok prategang parsial akan membuat gaya prategang lebih kecil dibandingkan prategang penuh sehingga tegangan tarik yang terjadi pada penampang balok akan lebih besar, dan tegangan tarik akan melampaui kuat tarik lentur beton hingga terjadi retak. Jika tegangan tarik semakin besar maka retakan yang terjadi akan semakin besar. Lebar retak dapat dihitung dengan menggunakan rumus Gergely-Lutz pada Persamaan 6.

$$
w_{\text {maks }}=k_{1} f_{s} \sqrt[3]{d_{c} A}
$$

halmana:

$w_{\text {maks }}=$ lebar retak maksimum, $[\mathrm{mm}]$,

$k_{1} \quad=$ koefisien yang tergantung kepada tipe tulangan pratekan dan non-prategang,

$f_{s} \quad=$ tegangan pada tulangan tarik, $\left[\mathrm{kg} / \mathrm{cm}^{2}\right]$,

$d_{c} \quad=$ selimut beton, [mm],

$A \quad=$ luas daerah tarik beton efektif di sekeliling tulangan utama dibagi dengan jumlah tulangan, $\left[\mathrm{mm}^{2}\right]$.

Nilai $k_{1}$ yang diambil untuk Persamaan 6 dalam perhitungan lebar retak adalah berbedabeda tergantung pada tipe baja yang dipergunakan. Nilai $k_{1}$ dapat dilihat pada Tabel 1. 
Tabel 1. Nilai $\boldsymbol{k}_{\mathbf{1}}$ untuk Rumus Gergely-Lutz

\begin{tabular}{ccc}
\hline Kategori & Tipe Baja & $\boldsymbol{k}_{\mathbf{1}}$ (dalam 10-6 ) \\
\hline 1 & Deformed Bar - Strand & 13,7 \\
\hline 2 & Deformed Bar - Wire & 20,3 \\
\hline 3 & Strand Only & 22,5 \\
\hline 4 & Wires Only & 37,2 \\
\hline 5 & Unbonded Tendon & 25,0
\end{tabular}

(Sumber: Dilger, W.H., \& Suri, K.M., dalam Kusuma, G. H., Tjio, V. S., \& Pudjisuryadi, P., 2000)

Dari rumus Gergely-Lutz, ACI memberi batasan lebar retak tidak boleh melebihi dari 0,25 mm untuk elemen eksterior dan 0,30 $\mathrm{mm}$ untuk elemen interior.

\section{METODOLOGI PENELITIAN}

\subsection{Metode Penelitian}

Prosedur penelitian yang dilakukan disusun dalam bagan alir pada Gambar 6.

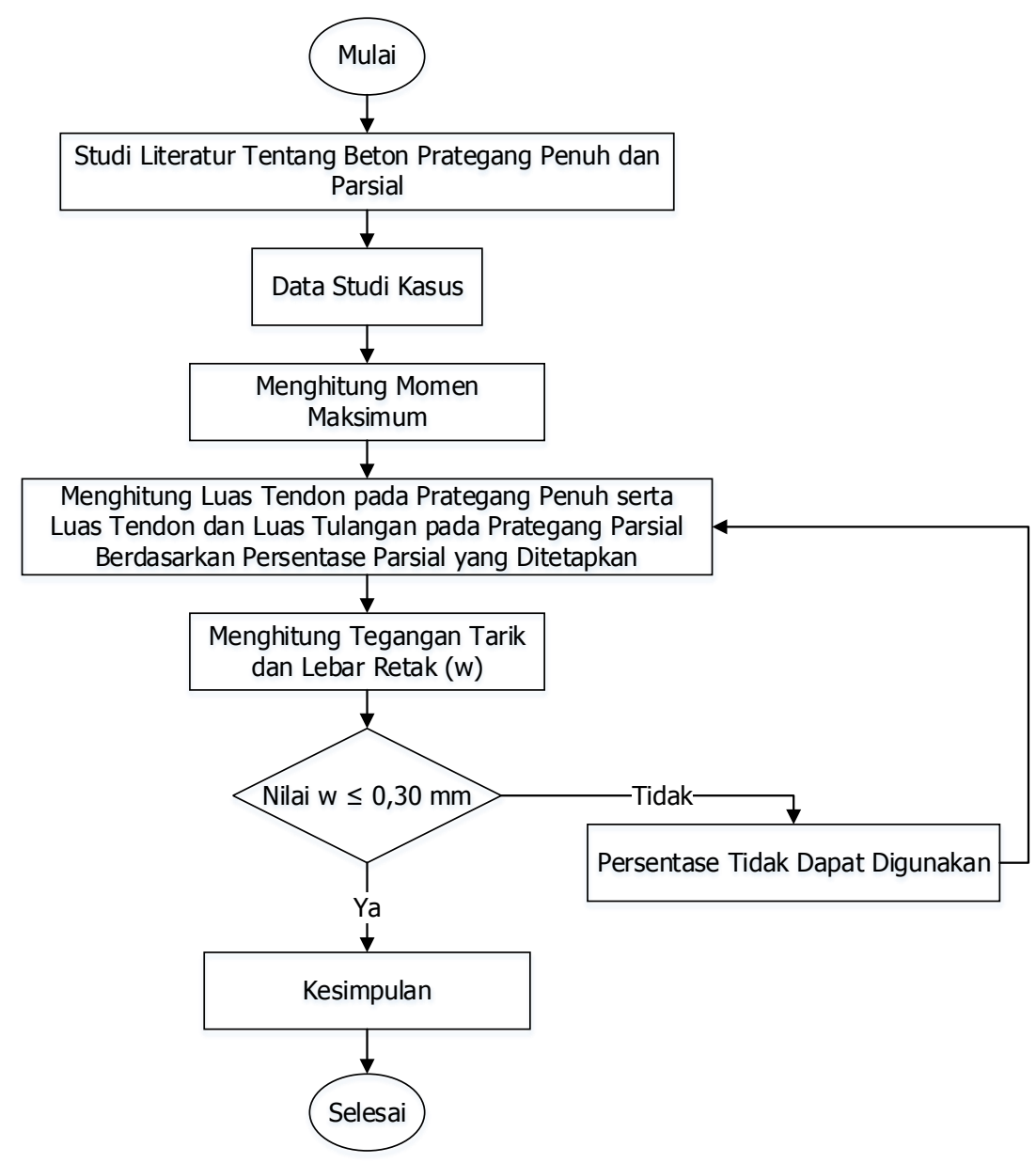

Gambar 6. Bagan alir prosedur penelitian

\subsection{Data Penelitian}

Data penelitian yang digunakan berupa data primer, yang terdiri dari:

(1) sistem struktur yang ditetapkan yaitu balok statik tertentu;

(2) bentuk penampang adalah penampang $T$ beserta dimensi penampangnya;

(3) bentang balok terdiri dari $18 \mathrm{~m}, 24 \mathrm{~m}$, dan $30 \mathrm{~m}$; 
(4) mutu material yang digunakan yaitu beton dengan $f_{c}{ }^{\prime}=35 \mathrm{MPa}$ dan baja tulangan dengan $f_{y}=400 \mathrm{MPa}$;

(5) kabel prategang yang digunakan yaitu kabel VSL ASTM A 416-06 Grade 270;

(6) persentase prategang yang digunakan dalam perhitungan adalah 50, 60, 70, 80, dan 90;

(7) pembebanan struktur;

(8) tegangan tarik maksimum dan lebar retak.

Detail dari bentuk penampang dan data dimensi penampang balok prategang yang digunakan dalam studi kasus dapat dilihat pada Gambar $\mathbf{7}$ dan Tabel $\mathbf{2}$.

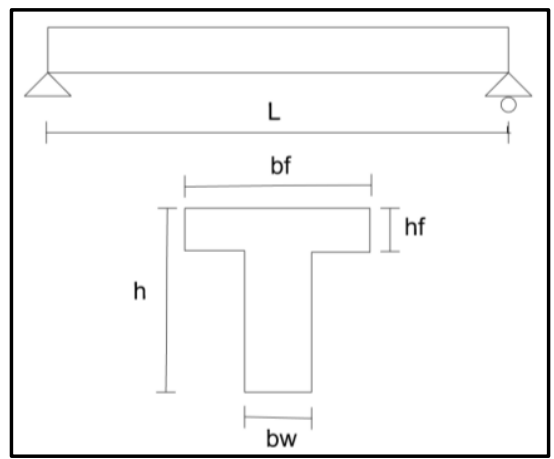

Gambar 7. Balok statik tertentu prategang dan penampang balok

Tabel 2. Data Balok Prategang

\begin{tabular}{ccccc}
\hline $\begin{array}{c}\boldsymbol{L} \\
{[\mathbf{m}]}\end{array}$ & $\begin{array}{c}\boldsymbol{h}_{\boldsymbol{f}} \\
{[\mathbf{c m}]}\end{array}$ & $\begin{array}{c}\boldsymbol{h} \\
{[\mathbf{c m}]}\end{array}$ & $\begin{array}{c}\boldsymbol{b}_{\boldsymbol{w}} \\
{[\mathbf{c m}]}\end{array}$ & $\begin{array}{c}\boldsymbol{b}_{\boldsymbol{f}} \\
{[\mathbf{c m}]}\end{array}$ \\
\hline \multirow{2}{*}{18} & 20 & 120 & 40 & 120 \\
\cline { 2 - 5 } & 20 & 140 & 40 & 120 \\
\hline \multirow{2}{*}{24} & 30 & 150 & 60 & 150 \\
\cline { 2 - 5 } & 30 & 170 & 60 & 150 \\
\hline \multirow{2}{*}{30} & 40 & 180 & 80 & 180 \\
\cline { 2 - 5 } & 40 & 200 & 80 & 180 \\
\hline
\end{tabular}

\subsection{Variabel Penelitian}

Variabel penelitian yang digunakan adalah persentase prategang yaitu 50,60, 70, 80, dan 90. Variabel persentase prategang ditujukan untuk mengetahui persentase prategang yang memenuhi batas lebar retak dan untuk mengetahui perilaku beton prategang parsial.

\subsection{Analisis Data}

Analisis data dilakukan dengan perhitungan manual menggunakan persamaan-persamaan yang ada. Analisis data terdiri dari:

(1) perhitungan gaya prategang penuh dan luas tendon yang diperlukan;

(2) perhitungan gaya prategang parsial serta luas tendon dan luas tulangan biasa yang diperlukan;

(3) perhitungan tegangan tarik maksimum dan lebar retak;

(4) membuat grafik yang menyatakan hubungan persentase prategang - tegangan tarik maksimum dan persentase prategang - lebar retak;

(5) menginterpretasi data grafik.

Grafik yang diharapkan adalah seperti pada Gambar 8 dan Gambar 9. 


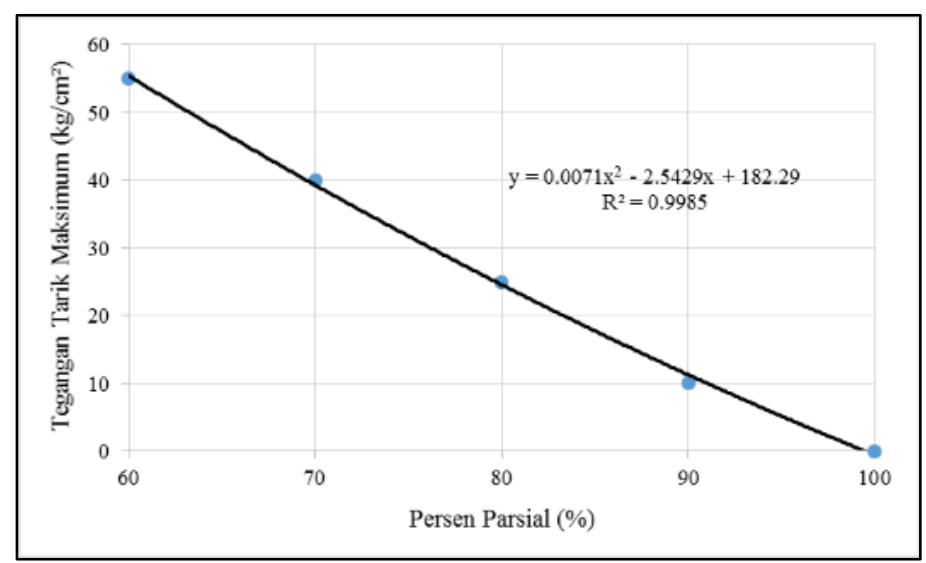

Gambar 8. Hubungan persen prategang dan tegangan tarik maksimum

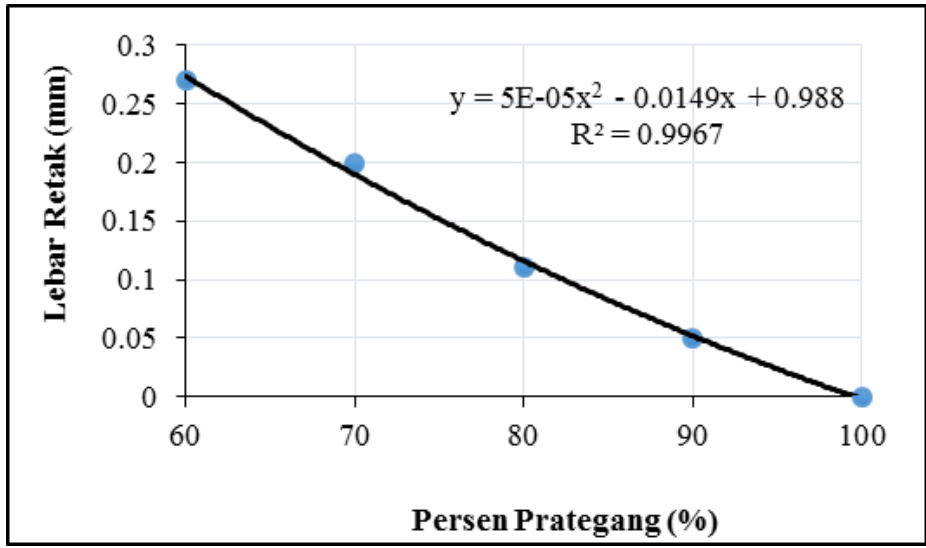

Gambar 9. Hubungan persen prategang dan lebar retak

\section{HASIL STUDI KASUS DAN PEMBAHASAN}

\subsection{Hasil Studi Kasus}

Hasil dari studi kasus yang dilakukan dengan perhitungan secara manual dapat dilihat pada Tabel 3, Tabel 4, Tabel 5, Tabel 6, Tabel 7, dan Tabel 8.

Tabel 3. Hasil Studi Kasus dengan Tinggi Balok $120 \mathrm{~cm}$ dan Panjang Bentang Balok 18 m

\begin{tabular}{ccccccc}
\hline \multirow{2}{*}{ Parameter } & \multicolumn{7}{c}{ Persentase Prategang } \\
\cline { 2 - 7 } & $\mathbf{1 0 0}$ & $\mathbf{9 0}$ & $\mathbf{8 0}$ & $\mathbf{7 0}$ & $\mathbf{6 0}$ & $\mathbf{5 0}$ \\
\hline Gaya Prategang $[\mathrm{kg}]$ & 225.000 & $204.731,2$ & 183.358 & $161.985,1$ & 140.612 & $117.439,7$ \\
\hline Luas Tendon Prategang $\left[\mathrm{mm}^{2}\right]$ & 1.638 & $1.490,58$ & $1.334,97$ & $1.179,36$ & $1.023,75$ & 855,04 \\
\hline Luas Penulangan $\left[\mathrm{mm}^{2}\right]$ & - & 630,51 & $1.269,68$ & $1.921,18$ & $2.591,15$ & $3.245,33$ \\
\hline Lebar Retak $[\mathrm{mm}]$ & - & 0,058 & 0,13 & 0,2 & 0,26 & 0,33 \\
\hline Tegangan Tarik Maks $\left[\mathrm{kg} / \mathrm{cm}^{2}\right]$ & - & 12,64 & 25,75 & 39,19 & 52,65 & 67,23 \\
\hline
\end{tabular}

Tabel 4. Hasil Studi Kasus dengan Tinggi Balok $140 \mathrm{~cm}$ dan Panjang Bentang Balok 18 m

\begin{tabular}{ccccccc}
\hline Parameter & \multicolumn{7}{c}{ Persentase Prategang } \\
\cline { 2 - 7 } & $\mathbf{1 0 0}$ & $\mathbf{9 0}$ & $\mathbf{8 0}$ & $\mathbf{7 0}$ & $\mathbf{6 0}$ & $\mathbf{5 0}$ \\
\hline Gaya Prategang $[\mathrm{kg}]$ & 200.000 & $179.233,5$ & $160.522,3$ & 141.811 & 122.115 & $102.419,1$ \\
\hline Luas Tendon Prategang $\left[\mathrm{mm}^{2}\right]$ & 1.456 & $1.304,94$ & $1.168,71$ & $1.032,48$ & 889,08 & 745,68 \\
\hline Luas Penulangan $\left[\mathrm{mm}^{2}\right]$ & - & 560,56 & $1.128,94$ & $1.708,46$ & $2.287,67$ & $2.876,58$ \\
\hline Lebar Retak $[\mathrm{mm}]$ & - & 0,051 & 0,112 & 0,16 & 0,22 & 0,27 \\
\hline Tegangan Tarik Maks $\left[\mathrm{kg} / \mathrm{cm}^{2}\right]$ & - & 9,74 & 20,13 & 30,52 & 41,45 & 52,38 \\
\hline
\end{tabular}


Tabel 5. Hasil Studi Kasus dengan Tinggi Balok $150 \mathrm{~cm}$ dan Panjang Bentang Balok 24 m

\begin{tabular}{ccccccc}
\hline Parameter & \multicolumn{7}{c}{ Persentase Prategang } \\
\cline { 2 - 7 } & $\mathbf{1 0 0}$ & $\mathbf{9 0}$ & $\mathbf{8 0}$ & $\mathbf{7 0}$ & $\mathbf{6 0}$ & $\mathbf{5 0}$ \\
\hline Gaya Prategang $[\mathrm{kg}]$ & 410.000 & $373.090,7$ & $334.142,3$ & $295.192,6$ & $254.193,6$ & $213.194,7$ \\
\hline Luas Tendon Prategang $\left[\mathrm{mm}^{2}\right]$ & 2.985 & $2.716,35$ & $2.432,78$ & $2.149,20$ & $1.850,70$ & $1.552,2$ \\
\hline Luas Penulangan $\left[\mathrm{mm}^{2}\right]$ & - & $1.172,26$ & $2.360,93$ & $3.573,03$ & $4.784,46$ & $6.016,3$ \\
\hline Lebar Retak $[\mathrm{mm}]$ & - & 0,057 & 0,13 & 0,19 & 0,26 & 0,32 \\
\hline Tegangan Tarik Maks $\left[\mathrm{kg} / \mathrm{cm}^{2}\right]$ & - & 11,91 & 25,65 & 39,39 & 53,85 & 68,31 \\
\hline
\end{tabular}

Tabel 6. Hasil Studi Kasus dengan Tinggi Balok 170 cm dan Panjang Bentang Balok 24 m

\begin{tabular}{ccccccc}
\hline \multirow{2}{*}{ Parameter } & \multicolumn{7}{c}{ Persentase Prategang } \\
\cline { 2 - 7 } & $\mathbf{1 0 0}$ & $\mathbf{9 0}$ & $\mathbf{8 0}$ & $\mathbf{7 0}$ & $\mathbf{6 0}$ & $\mathbf{5 0}$ \\
\hline Gaya Prategang $[\mathrm{kg}]$ & 380.000 & $345.843,2$ & $309.739,4$ & $271.734,6$ & $235.629,4$ & $197.624,7$ \\
\hline Luas Tendon Prategang $\left[\mathrm{mm}^{2}\right]$ & 2.767 & $2.517,97$ & $2.255,11$ & $1.978,41$ & $1.715,54$ & $1.438,84$ \\
\hline Luas Penulangan $\left[\mathrm{mm}^{2}\right]$ & - & $1.097,48$ & $2.210,49$ & $3.323,89$ & $4.480,18$ & $5.634,02$ \\
\hline Lebar Retak $[\mathrm{mm}]$ & - & 0,0412 & 0,103 & 0,16 & 0,21 & 0,27 \\
\hline Tegangan Tarik Maks $\left[\mathrm{kg} / \mathrm{cm}^{2}\right]$ & - & 8,42 & 19,88 & 31,91 & 43,36 & 55,4 \\
\hline
\end{tabular}

Tabel 7. Hasil Studi Kasus dengan Tinggi Balok $180 \mathrm{~cm}$ dan Panjang Bentang Balok $\mathbf{3 0}$ m

\begin{tabular}{ccccccc}
\hline \multirow{2}{*}{ Parameter } & \multicolumn{7}{c}{ Persentase Prategang } \\
\cline { 2 - 7 } & $\mathbf{1 0 0}$ & $\mathbf{9 0}$ & $\mathbf{8 0}$ & $\mathbf{7 0}$ & $\mathbf{6 0}$ & $\mathbf{5 0}$ \\
\hline Gaya Prategang $[\mathrm{kg}]$ & 680.000 & $618.818,1$ & $550.816,1$ & $486.214,9$ & $421.612,3$ & $353.610,3$ \\
\hline Luas Tendon Prategang $\left[\mathrm{mm}^{2}\right]$ & 4.951 & $4.505,41$ & $4.010,31$ & $3.539,97$ & $3.069,62$ & $2.574,52$ \\
\hline Luas Penulangan $\left[\mathrm{mm}^{2}\right]$ & - & $1.969,63$ & $3.944,34$ & $5.965,49$ & $8.040,97$ & $10.112,05$ \\
\hline Lebar Retak $[\mathrm{mm}]$ & - & 0,0604 & 0,14 & 0,201 & 0,24 & 0,32 \\
\hline Tegangan Tarik Maks $\left[\mathrm{kg} / \mathrm{cm}^{2}\right]$ & - & 12,92 & 28,41 & 43,12 & 57,83 & 73,32 \\
\hline
\end{tabular}

Tabel 8. Hasil Studi Kasus dengan Tinggi Balok $200 \mathrm{~cm}$ dan Panjang Bentang Balok 30 m

\begin{tabular}{ccccccc}
\hline \multirow{2}{*}{ Parameter } & \multicolumn{7}{c}{ Persentase Prategang } \\
\cline { 2 - 7 } & $\mathbf{1 0 0}$ & $\mathbf{9 0}$ & $\mathbf{8 0}$ & $\mathbf{7 0}$ & $\mathbf{6 0}$ & $\mathbf{5 0}$ \\
\hline Gaya Prategang $[\mathrm{kg}]$ & 635.000 & $574.647,7$ & $514.324,9$ & $454.003,6$ & $390.506,7$ & $330.183,9$ \\
\hline Luas Tendon Prategang $\left[\mathrm{mm}^{2}\right]$ & 4.623 & $4.183,82$ & $3.744,63$ & $3.305,45$ & $2.843,15$ & $2.403,96$ \\
\hline Luas Penulangan $\left[\mathrm{mm}^{2}\right]$ & - & $1.842,42$ & $3.708,92$ & $5.609,76$ & $7.504,42$ & $9.510,21$ \\
\hline Lebar Retak $[\mathrm{mm}]$ & - & 0,0609 & 0,12 & 0,18 & 0,24 & 0,28 \\
\hline Tegangan Tarik Maks $\left[\mathrm{kg} / \mathrm{cm}^{2}\right]$ & - & 12,36 & 24,88 & 37,40 & 50,58 & 63,11 \\
\hline
\end{tabular}

Hasil perhitungan studi kasus pada tabel-tabel diatas bila disajikan dalam bentuk grafik dengan membandingkan antara persentase prategang - tegangan tarik maksimum dan persentase prategang - lebar retak, maka hasilnya akan terlihat seperti pada Gambar 10, Gambar 11, Gambar 12, Gambar 13, Gambar 14, dan Gambar 15.

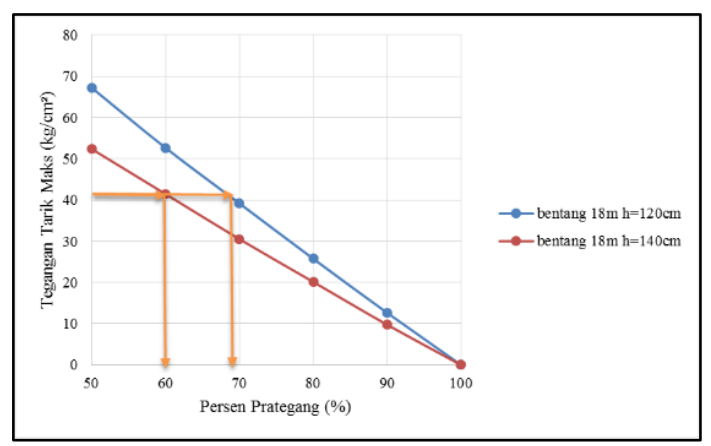

Gambar 10. Hubungan persentase prategang dengan tegangan tarik maksimum pada bentang $18 \mathrm{~m}$

Reka Racana - 56 


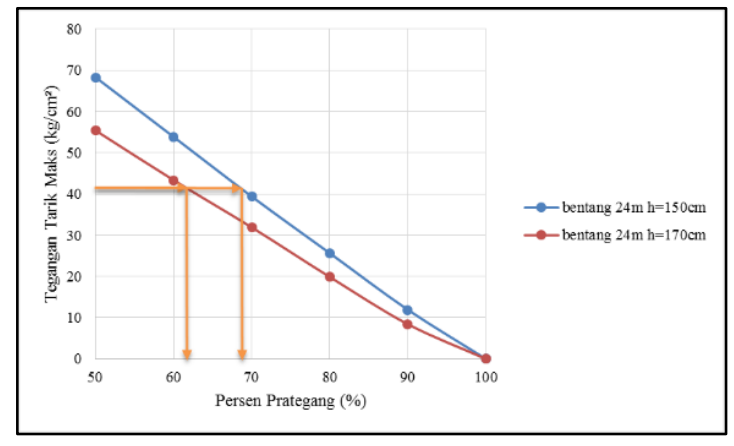

Gambar 11. Hubungan persentase prategang dengan tegangan tarik maksimum pada bentang $24 \mathrm{~m}$

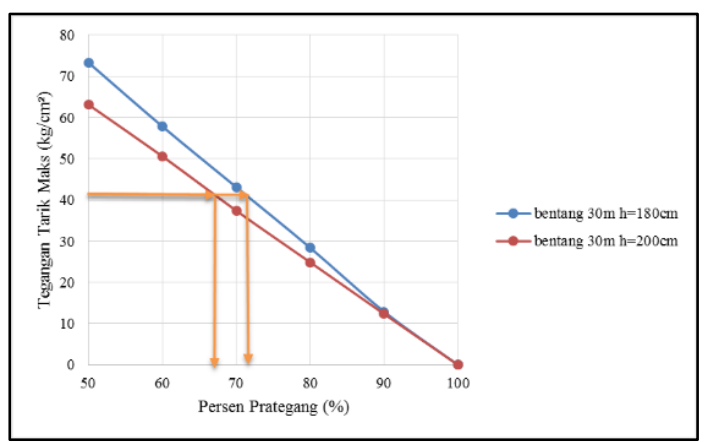

Gambar 12. Hubungan persentase prategang dengan tegangan tarik maksimum pada bentang $30 \mathrm{~m}$

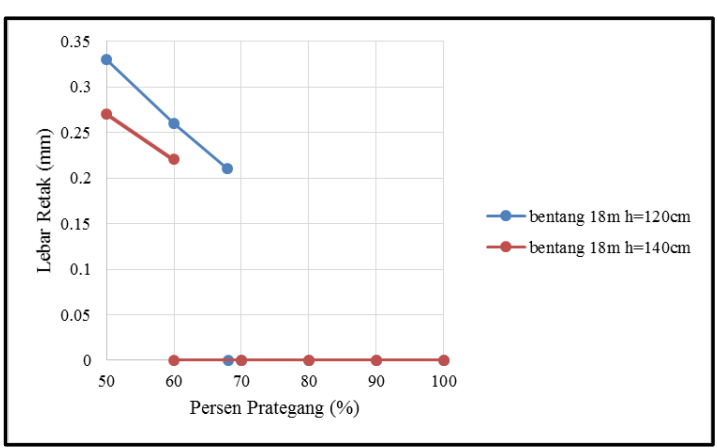

Gambar 13. Hubungan persentase prategang dengan lebar retak pada bentang $18 \mathbf{~ m}$

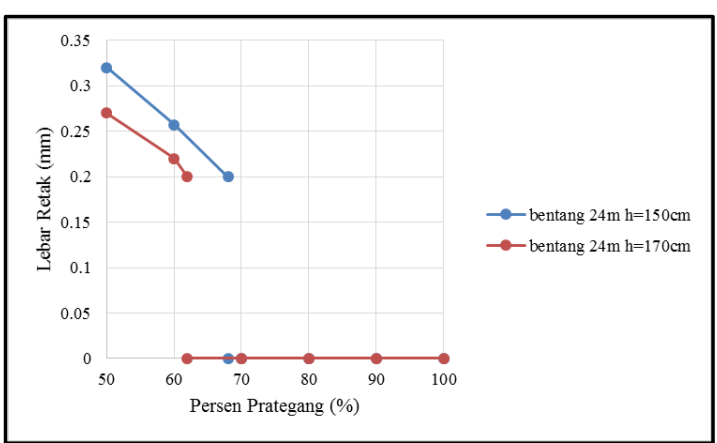

Gambar 14. Hubungan persentase prategang dengan lebar retak pada bentang $24 \mathbf{m}$ 


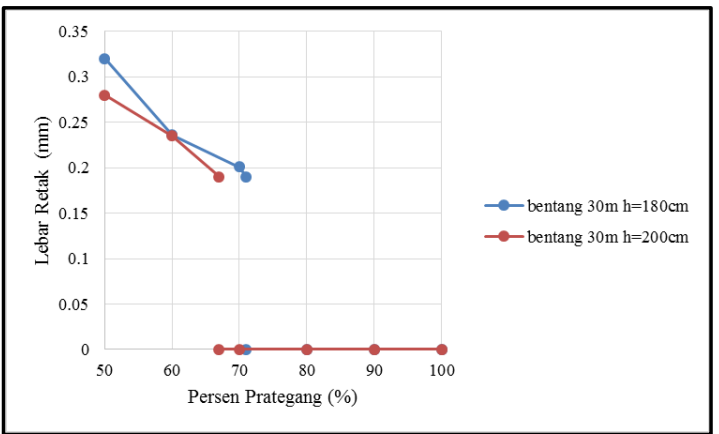

Gambar 15. Hubungan persentase prategang dengan lebar retak pada bentang $\mathbf{3 0} \mathbf{~ m}$

\subsection{Pembahasan Hasil Studi Kasus}

Hasil-hasil perhitungan memperlihatkan bahwa:

(1) besar persentase prategang yang digunakan berpengaruh terhadap tegangan tarik maksimum yang terjadi. Semakin kecil persentase prategang yang digunakan maka tegangan tarik maksimum yang terjadi semakin besar sehingga berpeluang akan menimbulkan retak;

(2) untuk suatu penampang dengan lebar dan tebal flange yang sama namun dengan tinggi yang berbeda, semakin tinggi penampang maka tegangan tarik maksimum yang terjadi semakin kecil seperti yang terlihat pada Gambar 10, Gambar 11, dan Gambar 12;

(3) retak mulai terjadi saat tegangan tarik maksimum pada balok lebih besar dari kuat tarik lentur beton yaitu sebesar $0,7 \sqrt{f_{c}{ }^{\prime}}$ atau $41,413 \mathrm{~kg} / \mathrm{cm}^{2}$. Dari hasil perhitungan tegangan tarik maksimum, retak terjadi pada:

a. Balok prategang parsial dengan bentang $18 \mathrm{~m}$ :

1) Penampang dengan tinggi $120 \mathrm{~cm}$, retak terjadi pada persentase prategang $68 \%$ dengan lebar retak 0,21 $\mathrm{mm}$. Lebar retak yang diizinkan sebesar $0,25 \mathrm{~mm}$ terjadi pada persentase prategang $62 \%$.

2) Penampang dengan tinggi $140 \mathrm{~cm}$, retak terjadi pada persentase prategang $60 \%$ dengan lebar retak $0,22 \mathrm{~mm}$.

b. Balok prategang parsial dengan bentang $24 \mathrm{~m}$ :

1) Penampang dengan tinggi $150 \mathrm{~cm}$, retak terjadi pada persentase prategang $68 \%$ dengan lebar retak 0,20 mm. Lebar retak yang diizinkan sebesar 0,25 mm terjadi pada persentase prategang $62 \%$.

2) Penampang dengan tinggi $170 \mathrm{~cm}$, retak terjadi pada persentase prategang $62 \%$ dengan lebar retak $0,20 \mathrm{~mm}$. Pada persentase prategang $60 \%$ lebar retak yang terjadi sebesar 0,22 $\mathrm{mm}$ dan belum melampaui lebar retak yang diizinkan.

c. Balok prategang parsial dengan bentang $30 \mathrm{~m}$ :

1) Penampang dengan tinggi $180 \mathrm{~cm}$, retak terjadi pada persentase prategang $71 \%$ dengan lebar retak $0,19 \mathrm{~mm}$. Pada persentase prategang $60 \%$ lebar retak yang terjadi sebesar 0,24 $\mathrm{mm}$ dan belum melampaui lebar retak yang diizinkan.

2) Penampang dengan tinggi $200 \mathrm{~cm}$, retak terjadi pada persentase prategang $67 \%$ dengan lebar retak $0,19 \mathrm{~mm}$. Pada persentase prategang $60 \%$ lebar retak yang terjadi sebesar $0,24 \mathrm{~mm}$ dan belum melampaui lebar retak yang diizinkan;

(4) untuk semua ukuran penampang, pada persentase prategang $60 \%$ lebar retak yang terjadi berada diantara 0,20-0,30 $\mathrm{mm}$. Oleh karena itu persentase prategang parsial minimum yang digunakan adalah sebesar $60 \%$ untuk menghindari lebar retak yang lebih besar dari yang diizinkan.

\section{KESIMPULAN}

Hasil dari studi kasus dan pembahasan yang telah dilakukan maka dapat disimpulkan bahwa: 
(1) karena terjadi tegangan tarik pada beton akibat penggunaan beton prategang parsial, maka pada analisis beton prategang parsial harus dilakukan pemeriksaan terhadap lebar retak yang terjadi akibat tegangan tarik tersebut;

(2) persentase prategang pada penggunaan beton prategang parsial harus dipilih sedemikian rupa sehingga lebar retak yang terjadi lebih kecil dari lebar retak yang diizinkan;

(3) untuk mutu beton sebesar $f_{c}{ }^{\prime}=35 \mathrm{MPa}$, batasan minimal persentase prategang pada penggunaan beton prategang parsial yang lebar retaknya tidak melebihi lebar retak yang diizinkan adalah $60 \%$.

\section{DAFTAR RUJUKAN}

Badan Standardisasi Nasional. (2002). SNI 03-2847-2002 tentang Tata Cara Perhitungan Struktur Beton untuk Bangunan Gedung. Jakarta: Badan Standardisasi Nasional.

Kusuma, G. H., Tjio, V. S., \& Pudjisuryadi, P. (2000). Perhitungan Lebar Retak pada Beton Pratekan Parsial dengan Unified Approach. Dimensi Teknik Sipil Vol. 2, No. 1, 9-21. 